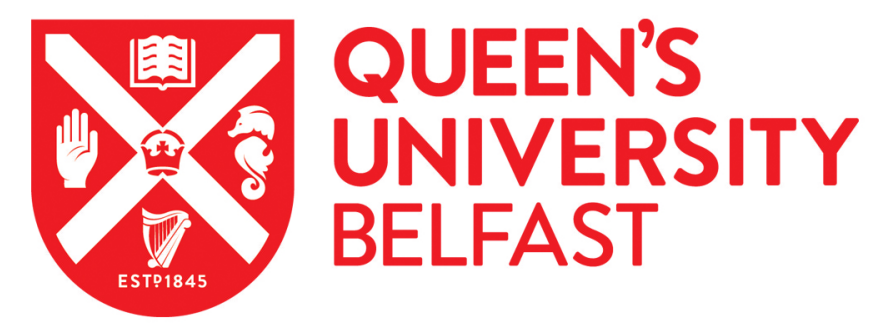

\title{
Afterlives: Testimonies of Irish Catholic Mothers on Infant Death and the Fate of the Unbaptized
}

Kennedy, L. (2020). Afterlives: Testimonies of Irish Catholic Mothers on Infant Death and the Fate of the Unbaptized. Journal of Family History, 46(2), 236-255. https://doi.org/10.1177/0363199020966751

Published in:

Journal of Family History

Document Version:

Publisher's PDF, also known as Version of record

Queen's University Belfast - Research Portal:

Link to publication record in Queen's University Belfast Research Portal

\section{General rights}

Copyright for the publications made accessible via the Queen's University Belfast Research Portal is retained by the author(s) and / or other copyright owners and it is a condition of accessing these publications that users recognise and abide by the legal requirements associated with these rights.

Take down policy

The Research Portal is Queen's institutional repository that provides access to Queen's research output. Every effort has been made to ensure that content in the Research Portal does not infringe any person's rights, or applicable UK laws. If you discover content in the Research Portal that you believe breaches copyright or violates any law, please contact openaccess@qub.ac.uk. 


\title{
Afterlives: Testimonies of Irish Catholic Mothers on Infant Death and the Fate of the Unbaptized
}

\author{
Liam Kennedy'
}

\begin{abstract}
Older Irish Catholics remember a metaphysical space or place called Limbo. This was the destination of unbaptized infants. They could never enter Heaven because the stain of original sin had not been removed. In addition, they were denied burial in consecrated ground. Fear of such eventualities drove parents to baptize as soon as possible. Nor was this a purely Irish phenomenon. In emergency cases, even baptism in utero was permitted in some parts of Catholic Europe. The centerpiece of this study is the testimonies of Irish mothers and their remembrances of the perils of Limbo, the disposal of infant corpses (in cillíni), and "churching." Why belief in Limbo has become almost extinct in recent decades is explored, drawing on both demand and supply side explanations. More generally, considerations of Limbo, the unbaptized, and the afterlife give rise to challenging questions as to secularization and even the definition of childhood.
\end{abstract}

\section{Keywords}

Limbo, baptism, childhood, cillíní, Catholicism, secularization

Children growing up in the Ireland of the 1950s will have a clear remembrance of a metaphysical space or place known as Limbo. For Catholics, though not Irish Protestants, this formed part of a spiritual cosmos that viewed Heaven and Hell as opposite poles, with Purgatory and Limbo occupying rather vaguely defined intermediate positions. Fast forward to the present day and hardly any of those born in the new millennium will have the slightest notion of what Limbo was (or is), other than as a figure of speech. A belief in Purgatory has also gone into decline, though some residual consciousness of a place of purgation, prior to entry into Heaven, seems to have persisted. Beliefs in Heaven and Hell, by contrast, remain widespread, even in post-Catholic Ireland with 85 percent holding a belief in Heaven and some 50 percent in the less comforting notion of Hell. ${ }^{1}$

A discussion of Limbo might appear to be largely or even exclusively the concern of theologians and clergy. But the burden of this paper is that the various theological assumptions and understandings

\footnotetext{
I Institute of Irish Studies, Queen's University Belfast, Northern Ireland, UK 
associated with this imagined afterlife had direct implications of a material and a psychological kind for people's lives, in Ireland and presumably elsewhere in the Catholic world. Thus, for those who believed in Limbo, it affected not only how they fared in the next world, in itself a consideration of inestimable importance, but it influenced their inner lives and their behavior in this life as well. What follows is an exploratory study of popular understandings of Limbo and their connections to childbirth, infant death and the disposal of the remains of unbaptized infants. It also discusses the deep roots of belief in Limbo, its place within the architecture of Catholic teaching, and, most puzzling of all, its silent retreat into the shadows of the later twentieth century.

This was of course a period of profound social and cultural change. Irish society became increasingly open to international influences: it broadened its trading links, direct foreign investment was encouraged, there was greater investment in secondary and tertiary education, living standards rose, television ushered in a new era of communication, church attendance declined, instances of clerical sex abuse multiplied while vocations to the priesthood and the religious sisterhood all but evaporated. ${ }^{2}$ By the opening decade of the twenty-first century the Irish economy was one of the most globalized in the world; immigration rather than emigration was the new reality; old authoritarian structures of church and state had crumbled; and many of the certainties of post-independence, Catholic Ireland had been discarded. ${ }^{3}$ Changes in the intellectual and moral climate were faintly evident in the 1960s and gathered pace in subsequent decades, but there was no "big bang" and even today a third of Irish adults attend a religious service at least once a week. ${ }^{4}$ The social process of liberalization and secularization has been gradual and evolutionary. But the important point is that it proved cumulative and so in the end transformational. Of particular significance in the present context, the role of women, once the primary bearers of social, sexual and religious values, had undergone fundamental change. "There was no social revolution in Ireland between 1922 and 1960," Earner-Byrne observes, "but it was a period of vital evolution which helped to redefine and redirect the future of Irish motherhood." $"$ True enough, though hardly at pace by comparison with other west European societies. But the later divisive debates on contraception, divorce, sex outside marriage, the treatment of unmarried mothers, the critique of patriarchal structures (including rejection by some of a male-dominated Catholic church), the decline of the cult of the Virgin Mary, and much else besides signaled the direction of change. ${ }^{6}$

\section{What Was Limbo?}

It is with some difficulty, therefore, that one comes to enter imaginatively a very different Ireland, one renowned for public displays of piety and conformity to prevailing social norms, one in which deviance was heavily penalized. A belief in Limbo, and the practices it entailed, was part of that world, and so needs to be introduced in a little more detail. The green-covered Catechism, in which generations of Irish schoolchildren were schooled and which carried the imprimatur of the then Archbishop of Dublin, Joannes Carolus (John Charles McQuaid), dated 1951, contained the essential elements of belief. ${ }^{7}$ The chain of concepts ran from the Fall of Adam and Eve, and hence Original Sin, and from there to Baptism and, in certain unfortunate circumstances, to Limbo.

The first parents of the human race were Adam and Eve. Adam ate the forbidden fruit in the Garden of Paradise and for this act of disobedience not only Adam and Eve but all subsequent humanity was punished. Here are the relevant excerpts from the Catechism. The time-worn format is that of a question, followed by an authoritative answer.

Q. 57: How do we call the state in which we are born because of the sin of Adam?

The state in which we are born because of the sin of Adam is called the state of original sin.

Q. 58: Why is original sin so called? 
Original sin is so called because it comes down to us through our origin, or descent from Adam, the head of the human race.

The next phase in the argument involves the sacrament of baptism as the gateway into the Catholic community, and ultimately into Heaven.

\section{Q. 344: Is Baptism necessary for salvation?}

Baptism is necessary for salvation, because our Divine Lord has said: Unless a man be born again of water and the Holy Ghost, he cannot enter into the kingdom of God (John iii, 5).

This gives rise to a terrible dilemma. Because original sin is stamped on the souls of all, including still-births and the newly-born, these souls cannot enter heaven unless they have received the sacrament of baptism, which is the only means to eternal salvation. This perplexed both theologians and parents and explains the rush to have infants baptized as soon as was practically possible, and sometimes even before birth (as we shall see later).

\section{Origin of the Idea of Limbo}

The term Limbo does not appear in the Bible or the New Testament and it seems the concept was developed over time by Christian thinkers to handle two problems: one was the fate of those who led just lives and who died before Christ came on earth to redeem humankind; the other was the fate of unbaptized babies in the event of death. The New Catholic Encyclopedia, published in 1967, saw the second as the prime issue. "The word [Limbo] in our times refers to the place or state of infants dying without the Sacrament of Baptism who suffer the pain of loss but not the pain of sense." ${ }^{8}$ Theological discussions of life after death for unbaptized infants go back at least as far as St. Augustine in the fifth century A.D. Because original sin was stamped on the souls of all the new-born, St. Augustine took the uncomplicated view that unbaptized children were plunged straight to Hell. ${ }^{9}$ Small wonder, as Diarmaid MacCulloch writes, that "creative Christian thinkers" might speculate about some middle state. ${ }^{10}$ Out of the ferment of theological speculation there emerged in the early Middle Ages a clerical construct known as "Limbus Infantium," a place where unbaptized babies were stored for all time, free from the torments of hell but unable to experience the joys of Heaven or of being reunited with their brothers, sisters, mother or father ever again. ${ }^{11}$

\section{The Approach}

What follows is a preliminary study, conducted in association with the Irish Countrywomen's Association (ICA), one that is possibly the first of its kind. It seeks to recover some of the varied understandings of Limbo once prevalent in Irish society, recollections that now sit precariously on the edge of living memory. The study proceeds to show how these beliefs shaped people's lives, sometimes inflecting them with great sadness. It is a story of anxieties around childbirth, infant death and exclusion from eternal happiness. The centerpiece is the testimonies of 26 mothers, 23 of them members of the ICA, whose help is gratefully acknowledged. These were elicited using a questionnaire distributed by the ICA in the spring of $2017 .{ }^{12}$ Some of the questions were open-ended so that respondents might elaborate as they saw fit. Many did so, revealing a deep vein of knowledge and insight. It is important to bear in mind also that different questions involved different time frames. Some related to the present or were purely factual such as geographical location or decade of birth while others sought historical information. Memories are reworked or reconstituted through time and not of course preserved in pristine form, as was once imagined. Still, in view of the intensity of religious socialization in Ireland, and the ubiquity and frequency of religious practice in the past, these limitations may be less severe than in other instances of retrospective inquiry. As Paul Thompson and 
others have argued in relation to the dangers of memory erosion, recalls of repeated and habitual events of personal importance tend to be relatively reliable. ${ }^{13}$ Cultural historians might entertain an additional worry, that discourses surrounding Limbo (in our particular case) might distort or "contaminate" memory. ${ }^{14}$ This is always a concern, although it would be hard to argue that discursive frameworks round Limbo commanded much public attention in the Ireland of the last half century.

In a small number of cases follow-up communication by phone or by e-mail was arranged. This allowed a more detailed exploration of some of the themes. Each respondent was guaranteed anonymity. There was no attempt to produce a representative sample, as this lay beyond the resources of the project. The approach is more in the spirit of an oral history initiative than a conventional social survey.

The internal evidence suggests that the voices presented here extend to a broad cross-section of older Irish women, while making no claims as to their representative character. For instance, the diversity of responses shows signs of a generational pattern, which is what might be expected in a society undergoing well-documented social and religious change. ${ }^{15}$ The incidental information on fertility captures the fertility transition evident in Irish society in the later twentieth century. The average number of children per mother was 4.1 for the sample as a whole; for those born in the $1960 \mathrm{~s}$ the average was two children. This finding of a sharp decline in marital fertility, which mirrors (though not exactly) the larger population, is reassuring. It is a tribute to the women who responded that virtually all of the questions were answered in a clear, often eloquent form.

The respondents were widely scattered across Ireland, and all four provinces were represented. The sample size is too small to engage in any kind of regional analysis, thus the results are presented at an aggregate level or given in individual detail. There may well be regional differences to the pace of change, there may be urban-rural differences, and there may be variation by socio-economic status. If so, teasing out such differences must await a larger study. As compared to large-scale, computer-assisted social surveys, where answers are plucked out of individual case context, there is the advantage here that the completed questionnaires were sufficiently manageable as to allow each to be read as a complete document. The semi-structured nature of the questionnaire also allowed for a flow of remembrances that would not easily find its way into a more rigid format.

The opening question in the survey sought to get a sense of the age of the respondent because attitude and behavior are likely to have varied as between generations. The age breakdown was as follows: two were born in the 1930s, nine in the 1940s, eleven in the 1950s and three in the 1960 s, or twenty five in all. (One respondent did not include her decade of birth.) This is a good spread and, with the exception of those born in the 1960s, it is clear that we are dealing with generations of women socialized into beliefs in Limbo, and who also experienced traditional understandings of Catholic teaching on this and other elements of belief. ${ }^{16}$

\section{What Kind of Place Was Limbo?}

Images of Limbo entered the imagination of young women but seemingly took different, sometimes phantasmagorical forms. It is not possible to do justice to the range of views and emphases, short of reproducing all of the responses, but the following are representative impressions. A mother who was born in the late 1940s visualized Limbo as "some dark place, never to see the sight of God. I imagined it like a cave, not to see any light again." Another respondent from the same era wrote as follows: "I didn't think about it much. Perhaps visualised some sort of a dark corridor with strangely-shaped 'people' - tiny creatures - waiting." The implication may be of waiting for admission to Heaven and this expectation is mentioned in a number of the responses.

Some did not share this expectation, however. One writes: Limbo was "A dark area where unbaptised babies went. They would not ever get to heaven." A mother from County Cork, and one of the younger respondents (born in the early 1960s) viewed Limbo as "A not so nice place where you were 
stuck forever because you had original sin! Scary place as a child." This echoes the opinion of another mother, also born in the 1960s, who saw Limbo as a "No Man's Land." She goes on to say that those who went there were "locked out of Heaven and had nowhere to go." She places Limbo in a celestial setting, located "between Heaven and Purgatory," adding that it was a lonely place. A response from County Meath that reflects Church teachings at the time ran as follows: "Asked my mother what limbo was, as a child. Explained by my Mother that babies couldn't go to church or be buried at the cemetery, if not baptised. As they still had original sin." The theme of burial grounds for unbaptized babies is one we will return to.

Most respondents recalled Limbo as a gloomy state: "Darkness. No pain or punishment but the loss of God"; "a dark, lonely place of waiting"; "not a very nice place"; "a place where one never saw God." Another elaborated: "I think it was a place where lost souls floated around indefinitely, no pain, no feelings, just an aimless existence, neither a good nor a bad place, the main point was that they were lost souls going nowhere with no escape route, unlike purgatory where there was hope that at some time they might be released. However, it was always instilled in us that these lost souls were blameless."

But not all viewed Limbo as inhabited by "lost souls" of one kind or another, though admittedly the following are minority viewpoints. A County Donegal woman who would no longer consider herself a practicing Catholic mentions: "I don't recall thinking too long and hard about the subject to be honest! But it wouldn't have been a negative place to my young mind." The childhood recollection of another mother was of a "lovely peaceful place but lonely." A more detailed account was furnished by a mother who was born in the 1940s:

Limbo was a place where babies and people who had died without their sins forgiven went to before they were clean enough to enter heaven. A happy enough place! We spent our childhood at All Souls Night in and out of the church praying for the relatives who had died, to send them from Limbo and help them enter Heaven. All the Parish did this! Saying 1 Our Father, 10 Hail Marys and 1 Glory be to the Father each.

You spoke to no-one while doing this. It was always very dark, you could only barely make out the other hundred people doing the same. But it was a ritual I liked doing. I felt I was helping the relatives who had died. It made a connection with them.

The eschatology may be a little awry as two distinct states or judgments about the afterlife, that of Purgatory and that of Limbo, are being fused and confused but this is a wonderfully vivid picture of popular Catholic piety as it related to communion with the dead and the plight of souls in the "other world." It is in accord with a long-standing Christian belief in a community of the living and the dead, a belief found in many religions. Timewise it relates either to the end of the 1940s or the early 1950s (as the respondent's decade of birth was the 1940s). She concludes by saying: "But I don't believe the innocent babies go to Limbo or anywhere else. I believe my granddaughter who was miscarried is with my mother happy and content—wherever they are."

Another expressed a positive assessment of Limbo, though with the qualification that she hadn't given the different manifestations of the "other world" much thought. There is also possibly a strain of skepticism (taking the totality of her responses into account). Here is what she had to say:

I thought it was a place of happiness. I never thought too deeply on these places, "heaven, hell, purgatory, limbo." I could never figure the whole thing out so I just went along with it. My parents were Catholic and practised as was laid down. . The previous generation, my granny, thought all these departments were up in space and wondered did the astronauts see any sign of Heaven.

Clearly Limbo meant different things to different people, though there is little doubt that most viewed it as an undesirable place or state of being. There is an impression also from the various 
testimonies, irrespective of the standpoint adopted, that the characteristics of Limbo were only weakly sketched by those who felt a responsibility for passing on these beliefs. The contrast with traditional Catholic teaching on Hell, for instance, is marked. There was nothing vague or shadowy about the terrors of Hell. ${ }^{17}$ A majority of the respondents saw Limbo as an intermediate state: "a place where children were in until they went to heaven." Some however did not take Heaven to be the ultimate destination, and so entertained the frightening prospect that there was no escape for all of eternity (in line, it has to be said, with orthodox Catholic belief).

\section{The Timing of Baptism}

In view of the potential danger of one's child ending up in Limbo and facing the prospect of loss of one kind or another, there was an understandable emphasis on having the infant baptized as soon as was practicable. The burden of guilt for failure to baptize devolved to the mother. Guarding against such a prospect was all the more necessary in periods of high infant mortality, as was the case in most parts of Europe until after World War II. ${ }^{18}$ In Ireland, at the beginning of the twentieth century, one in ten children died within a year of birth. The proportion was higher still in the two major cities, Dublin and Belfast. There had been only limited improvement in the Irish Free State, later Irish Republic, until the widespread use of antibiotics after World War 11. In 1943 infant mortality stood at more than 80 in every 1,000 births, before entering a largely uninterrupted decline thereafter. Still, it was not until the 1970 s that infant mortality dipped below 20 per $1,000 .{ }^{19}$ Thus the common experience of child mortality and popular understanding of religious duties ought to predispose parents in the direction of early baptism. But was Church orthodoxy on early baptism translated into practice? So far as we know, it was, and with remarkable rigor. What little research there is points unequivocally in the direction of a practice of early baptism, at least down to the $1960 \mathrm{~s}^{20}$

Baptism was normally administered by the parish priest or his curate but in the event of danger of death parents and other lay persons could perform the ceremony. One mother speaks of "my dear little angel who died ten minutes after birth. The baby was baptised by a lovely nurse after birth." This, incidentally, is the only instance in the survey where a reference is made to baptism by a lay person, though we know that Catholic nurses and other medical practitioners were instructed in how to respond to a spiritual as well as a medical emergency. One retired hospital consultant told me that on the labor ward there was always a bottle of holy water to hand, should the occasion arise. ${ }^{21}$ On the Irish-speaking peninsula of Dingle in County Kerry the phrase baiste an úrláir (baptism of the floor) is part of the local vocabulary relating to baptism by lay persons. ${ }^{22}$

The importance of emergency baptism was heavily underlined in Catholic publications, including medical journals. It was permissible, for instance, to baptize in utero; it was permissible also to rupture tissues and membrane surrounding the fetus, so as to allow the baptismal waters to find direct contact with the unborn. ${ }^{23}$ In Belgium, another largely Catholic society, medical students and birth attendants were given training in emergency baptism, including baptism in the womb. If the birth was difficult, obstetrics' manuals and the Catholic hierarchy advised that a baptismal syringe be inserted into the vagina so as to bring water to the head of the fetus. If the infant was later delivered alive, baptism had to be repeated to make certain that the baptismal water had reached the head. ${ }^{24}$ Intrauterine baptism was also practiced in France and midwives were instructed in this spiritual duty. ${ }^{25}$ How painful the use of instruments such as syringes and pipettes in the administration of baptism might be, it is hardly possible to say. If nothing else, these interventions point to the fundamental significance of baptism within Catholic theology and concerns that the eternal life of the fetus or infant not be compromised. ${ }^{26}$ Inevitably these concerns spilled over into the realms of medicine, politics and nursing. ${ }^{27}$

This survey presents some limited information on parental decisions in relation to the timing of baptism, though it should be noted that most of these births were occurring from the 1970s onward 
Table I. The Interval between Birth and Baptism.

\begin{tabular}{lcccc}
\hline Interval & $\begin{array}{c}\text { Within Three Days } \\
\text { (Percent) }\end{array}$ & $\begin{array}{c}\text { Four to Seven Days } \\
\text { (Percent) }\end{array}$ & $\begin{array}{c}\text { Eight to Thirty-one } \\
\text { Days (Percent) }\end{array}$ & $\begin{array}{c}\text { Greater than Thirty-one } \\
\text { Days (Percent) }\end{array}$ \\
\hline First-born & 8 & 20 & 48 & 24 \\
Last-born & 0 & 8 & 56 & 36 \\
\hline
\end{tabular}

when notions of Limbo were receding. As is apparent from Table 1, most of the first-born children (76 percent) were baptized within a month of birth; in a minority of cases ( 24 percent) the interval between birth and baptism was more than one month. The number of cases is twenty five as one return omitted this information. Thus, traditional baptismal practices were undergoing change but not yet to the extent apparent nowadays. The pattern for the last-born child of these mothers shows a shift over time toward later baptism. The two mothers, for instance, who had had their first child baptized within three days delayed baptism for the final child by more than a week in one instance and by more than a month in the other. What this tells us is that behavior within the same family in relation to baptism could change by birth order and over time.

The shift to longer birth-baptism intervals had important implications of a gender-specific kind, some of which are not immediately apparent. It meant that the mothers could attend the baptism ceremony, something that was not possible under the traditional regime of almost immediate baptism. In another sign of the changing times, all of the births were in hospitals or nursing homes: the era of home births had passed, though this had been commonplace in rural districts as late as the $1940 \mathrm{~s} .{ }^{28}$ Nonetheless, most of the baptism ceremonies were performed at the baptistery in the church, as prescribed by Canon Law. This also happened to chime with the financial interests of the priest, as a fee was normally charged. ${ }^{29}$

\section{"Churching" of the Mother}

This brings us to a controversial area relating to the rituals surrounding childbirth and one on which there are divided opinions. This was the practice of "churching" the mother after birth and before she could be allowed to participate fully in the celebration of the Mass. The modern version is described as "a blessing given by the Church to mothers after recovery from childbirth," though older formulations implied a ritual of purification. ${ }^{30}$

Not all of the mothers in our survey experienced "churching." Less than one-third reported they had undergone the ceremony after the birth of their first child. This was seven of the mothers, and six in the case of last births. A mother who was born in the 1930s was churched after the birth of her first child in 1963 but the birth of her seventh and last child in 1977 was followed by a "blessing" rather than the traditional ceremony.

One of the respondents, while still a schoolgirl, happened to observe a ceremony in her convent chapel that she took to be a case of churching. The observations are intriguing, because they suggest a consciousness of churching among some schoolchildren circa 1960 and also because it is not clear if this really was a case in point. Could nuns for instance administer a form of churching?

I recollect attending day secondary school, Middleton, Co Cork 1959-1964. One day, possibly in 1960, the cleaning lady, Mrs O'Reilly, had another baby, maybe her fifth child. She was back cleaning up after us quite soon after the birth. I remember one day visiting the Convent chapel before we left for the train and saw Mrs O'Reilly in there with her baby and one of the nuns praying over her and giving them both a blessing. One of my wiser friends said she was being "churched." That's my only brush with the activity. 
How mothers experienced churching is an important consideration. There is an eloquence to many of the testimonies but it may be helpful before reading on to recall the two questions that were posed in the survey. First, were you churched after the birth? If so, how did you feel about this at the time? This is the response of a mother who gave birth for the first time in 1969: "Very strange it was the first time. I'd heard of churching. My mother took me to the Church, we sat in the back seats. A priest came out to church me, this had to be done before I could enter the Church for mass or sacraments." This is a good summary of the practice and it also introduces the role of the older mother in both a supportive role and as a bearer of tradition.

Other responses indicate a depth of emotion, bordering on anger, toward this Church practice. These are the words and feelings of three of the women: [I felt] "terrible, easily known priests didn't have babies"; "Angry, as it was only the woman (not the man)"; "Upset. Made me feel it was sinful to have created new life." But one mother whose first child was born in 1976 simply responded to the question on how she felt after being "churched": "Good." 31 Another of an earlier generation, who had her first child in 1960, said she felt "OK."

Some women who were not "churched," and hence typically younger, held strongly gendered views on the subject. According to one, she was "very annoyed that there was churching of women only." Another mother - her first child was born in 1981 — had more wide-ranging criticisms. She recalls: "when I read somewhere about this practice I was truly horrified. It laid the ground stone for regarding sex, reproduction and women [as] unclean. It quite put males on a different upward level."

Some were simply dismissive of the notion of churching. "I had heard about it but thought it was ridiculous." 32 However, the modern replacement for "churching," that of offering a thanksgiving blessing by a priest after birth, drew a favorable response from three of the mothers. So, a distinction was being drawn between a traditional practice which some at least saw as misogynistic (though possibly when reflecting back at a later stage in life) and a more modern adaptation. Fuller speaks of a "new theology" finding expression in the aftermath of Vatican II (1963-1965) which modernized the rituals associated with birth and baptism. ${ }^{33}$

An attempt at summarizing these varied responses might run as follows. A minority of the women who had been churched said they found it acceptable and perhaps even a positive experience. But most said they found it objectionable, at least in retrospect and some possibly at the time. (There is always the danger, here as elsewhere, that current attitudes are being projected backward to an earlier period in time, though some of the criticisms are so forthright that they suggest longstanding feelings on the subject.) Moreover, some women who had not been churched went out of their way to pour scorn on the very idea of the practice. ${ }^{34}$ There are certainly flashes of resentment along gender lines at a ceremony that was perceived as discriminating against women. Though the survey was not designed to explore the issue in any detail, it seems unlikely that the view expressed above by one of the respondents, linking churching to repressive clerical attitudes toward sex and reproduction, was or is an isolated opinion. ${ }^{35}$

\section{The Burial of Unbaptized Babies}

The Irish countryside contains many reminders of how unbaptized babies were disposed of in the past. Or to borrow a metaphor from an Irish poet of place, John Montague, the landscape can be seen as a manuscript awaiting its reader. ${ }^{36}$ The Irish-language term, cillin, refers to patches of ground in which were interred unbaptized babies, often stillbirths, and sometimes suicides and strangers (such as drowned sailors washed ashore) whose baptismal status was unknown. ${ }^{37}$ Pregnant women who died before giving birth might also be excluded from consecrated ground. ${ }^{38}$ Some parishes had more than one cillín, so there may well have been thousands of these sites dotted across the island at one time or other. The locations were often in remote places, as mentioned in this piece of oral evidence from the 1930s. ${ }^{39}$ The dynamic between the living and the departed is implied. "Táid suidhte in 
Table 2. Disposing of the Corpses of the Unbaptized Infants.

\begin{tabular}{lcc}
\hline Location & Number of responses & Proportion of responses (Percent) \\
\hline Family grave & 7 & 30.4 \\
Other part of the cemetery & 4 & 17.4 \\
Outside of the cemetery & 5 & 21.7 \\
Unsure/do not know & 7 & 30.4 \\
& 23 & 100 \\
\hline
\end{tabular}

áiteanna an-chiúin. Bíonn eagla ar daoine nuair a bhíonn siad ag dul thairsti mar bíonn siad anuaigneach istoidhche." (They are situated in very quiet places. People are afraid when they pass them because they are very lonely at night-time.) Many of these cillíní have softened into the landscape with the passage of time and their presence is overlooked but on the Dingle peninsula, for instance, the outlines of cillíní are still visible to the naked eye and locally knowledgeable people can point out locations in many other parts of Ireland. ${ }^{40}$

The archaeological evidence indicates that the practice of excluding unbaptized babies from Catholic cemeteries goes deep in time, to the sixteenth and seventeenth centuries and the aftermath of the Counter-Reformation. ${ }^{41}$ More than 1,400 cillíní have been identified across Ireland, and in every county, but most are concentrated in the western, once Gaelic-speaking counties of the island. ${ }^{42}$ To repeat, the unbaptized were not part of the Christian community, by virtue of not having had the stain of Original Sin expunged from their souls. As a consequence, they were deemed unfit to share consecrated ground with baptized Catholics. A compromise in some localities was to designate an obscure part of the cemetery as a burial ground for unbaptized babies. In Middleton, County Cork, for instance, it is related in the survey that there was a "communal area for babies in a corner of the cemetery-with no names." These infants were typically stillbirths or neo-natal deaths. The so-called "Angels Plot" in Glasnevin Cemetery, Dublin is said to contain the remains of more than 50,000 babies. ${ }^{43}$ Milltown cemetery in the west of Belfast has a boggy area, situated away from the main burial grounds where thousands of unbaptized babies are said to be buried. ${ }^{44}$

The survey sought to get some sense, not of the origins but of how recent the exclusionary practices might have been. It is worth bearing in mind that we are drawing our information from mothers who gave birth in the second half of the twentieth century. So perhaps the really surprising finding to emerge from Table 2 is that only a minority of unbaptized infant corpses may have been placed in the family grave. At least that is the impression that is conveyed by these respondents in relation to their own localities. The quantitative estimates presented in the table should not be given too much emphasis - the sample is small, a few did not answer, and a quarter of respondents were not acquainted with their local parochial burial protocols - but what information there is points in the direction of practices that discriminated against unbaptized babies, not just in earlier times but into the second half of the twentieth century. Of the five who mentioned that stillbirths and early infant deaths were totally excluded from sacred ground, one mother was born in the 1930s, two in the 1940 s and two in the 1950s. There is an age gradient to the responses as younger mothers either had no direct personal experience — a consequence of declining peri-natal mortality — or burial practices had been liberalized locally.

These were the practices, at least in some localities. It is now time to consider how these practices were experienced. The testimony of one of the mothers has such a piercing quality it is worth documenting at length.

I was born in 1948 in my grandparents' house on a Sunday morning [and] was baptised the following Sunday in Church. I was the eldest of ten children. But in 1954 I had a sister born named Marian (as 
it was Marian year in Ireland). She was born on a Saturday but died the next day. As was customary then my Dad had to take her little body late at night well after dark to an old graveyard and on the perimeter of the graveyard my Dad had to bury her with no grave markings (an unknown grave). But at the time he made a little cross shape tied together with twine, made from two sticks and stuck them in the ground. Every year my Dad used to take me to Marian's grave to say a little prayer.

He used to say she was a little "angel in Limbo." All because she hadn't been baptized. That old Churchyard has been tidied up and over the last ten to fifteen years the local priest says a mass/prayers once a year. Many people go along and some of us have placed little crosses/markers where our little angels have been buried back in the ' $50 \mathrm{~s} \ldots$.

This tallies with another account from a mother who was born in the 1950s: "they were buried outside the cemetery, maybe in a ditch." A younger mother, born in County Monaghan in the 1960s (she had her first child in 1999), mentions in the case of her mother that she had lost a child soon after birth. The remains were buried soon after in the family grave but the family did not attend the burial. In further correspondence she kindly outlined some further circumstances. Her father got a little coffin and set off for the hospital. He and her uncle buried the infant, in what must have been a lonely funeral at the family grave. In Ireland funerals are usually large gatherings of family, kin, neighbors and friends - an occasion of sociability and communal solidarity. The difference on this occasion underlines the abnormality of these kinds of furtive burials. Nor was there any religious ceremony at the graveside. It was "a private thing," she says, and it wasn't spoken about much. "My mother's baby was carried to full-term even though it was known that the baby had died approx six weeks before its due date." She continues:

Our neighbours would have known she was pregnant but no one would speak about her loss. It was such a private matter at that time and the only conversation she would have had would have been with my Dad, the nurses and doctor. My mother never seen the baby and the nuns in the nursing home told her that it was for the best. The baby was deformed-looking. My mother accepted this. We were told about the death at the time and that Dad was going to bury the baby.

Despite or perhaps because of the sense of grief and loss, Limbo was not far from their thoughts:

We were aware even though we were young at the time that the baby was gone to Limbo.... The nurses were nuns and my mother said they were very kind and looked after the mothers very well. The baby boy was never named. We don't really talk to my mother about it as we know it would be sad to remind her about that time. My mother and mothers of my friends who had lost babies would have the same experience.

Our baby brother would have been born in the late $60 \mathrm{~s}$ or early $70 \mathrm{~s}$. I am not sure of the date. I went to a mission where all unbaptized babies were remembered and you could name the baby. I told my mother about the special remembrance I attended and she was delighted. I put my own name on the baby and participated in the prayers and candlelit procession. In Cavan hospital every year they have a mass for unbaptized babies and they are remembered. It's such a lovely way to remember those babies who didn't make it and are now acknowledged. My mother is in her ninetieth year and is a very resilient lady.

It's all there, is it not? We notice the silences, the awkwardness, perhaps a touch of shame, the pain of grieving, the emotional imprint on the next generation, and the efforts of the Catholic Church in more recent times to address the deep sadness affecting parents and the wider family. ${ }^{45}$ There is support for the value of these rites and practices from a perhaps unexpected quarter, that of modern psychology. One strand of bereavement theory recognizes that "death ends a life, not necessarily a relationship," as indeed observant Catholics have always believed. This approach to grieving 
assumes that "the relationship and the emotional link with the loved one can be continued and this has been found to be especially important in the case of losing a child." 46

Nor were the barriers to giving support and understanding, either in liturgical or in personal ways, confined to the Catholic community in Ireland. The first woman to become an Anglican bishop in Ireland or Britain, the Most Rev. Pat Storey, Bishop of Meath and Kildare, has written of the prevailing culture in previous generations whereby people "seldom talked about or acknowledged miscarriage or loss." She herself had undergone the pain of losing three babies through miscarriage. In her view "society has been slow to acknowledge the loss of a baby through miscarriage, stillbirth or neonatal death... Indeed, in the church too we have had no liturgy that might help to navigate the turbulent waters of this kind of loss." 47

\section{The Fading of Limbo}

For generations of Irish Catholic mothers the pain and the joy of giving birth was closely associated with infant mortality and concerns about the spiritual as well as the temporal welfare of the child. Adherents of Irish Protestant denominations, it may be noted, entertained no such apprehensions as these faiths did not include a belief in Limbo. ${ }^{48}$ Within Catholic Ireland the existence of cillíní and the exclusion of unbaptized babies from consecrated ground pointed to fears surrounding birth, baptism and the world beyond the grave. The danger of an infant missing-out on eternal happiness was the specter that haunted motherhood and birth-giving. This was in addition to other concerns of a kind common to all mothers around the time of giving birth, of which maternal mortality was an ever-present danger. Yet few subscribe to notions of Limbo nowadays and the days of early baptism are largely in the past.

So, when did these once all-pervasive beliefs regarding unbaptized infants give way to different conceptions of the afterlife? The survey results suggest considerable vagueness on the timing of the transition, and quite a few added that they were unsure. This in itself is significant as it suggests that the fading of Limbo was a largely unremarked process within Irish society. There was no watershed moment, as with the acceptance of same-sex marriage (to take a recent example), but rather a progressive and barely perceptible decay of a once powerfully-held belief. ${ }^{49}$ A larger survey might well find variations in the process of change as between different parishes and dioceses. A host of social variables might be at play, including differences in age, gender, education, socio-economic status, and much else besides. Moreover, as with birth control nowadays, different priests and nuns might communicate differing interpretations as to what was morally correct.

It is perhaps appropriate that the decline of a nebulous nether world, such as Limbo, should itself be subject to an uncertain, extended and barely perceptible demise. Of one thing, though, we can be fairly sure. It is that belief in Limbo and the associated fears for the eternal welfare of the unbaptized infant persisted into the 1960s, and in the hearts and minds of some parents for longer.

\section{Why the Decline of Belief in Limbo?}

Now we come to a crucial question. Why were deeply-rooted beliefs in the existence of Limbo simply neglected or discarded in the later twentieth century? A few preliminary points may be made. Tracing change in religious beliefs is a notoriously elusive enterprise, as is identifying the determinants of change. There is also the fragility of memory to contend with as the memory process is an active one, inevitably involving reconstructions of past experience. ${ }^{50}$ Nonetheless, the experiences recounted here are so salient to the lives of Catholic mothers that distortion, other than of an unconscious kind, is unlikely to have fatally colored the responses. Those commenting in the survey on the decline of Limbo fall into two broad categories. Only one person expressed no view. A clear majority (three-quarters) placed the emphasis on changing beliefs and values on the part of the laity. The 
remaining quarter saw the source of change as coming from on high, from the clergy and hierarchy of the Catholic Church. To simplify a little, the explanatory sketches ran in terms of Priests or People.

The People were viewed in the survey as responding to a variety of influences, located mainly at the societal level. Several mention the importance of education in coming to new ways of thinking about Limbo. The result according to one respondent was that "more people [were] less accepting of Church/Catholic myths." Linked to education but not only to education was a more questioning attitude. As one mother put it: "Young people became more educated and began to question stuff that did not make sense to them. They were no longer afraid of the 'fire and brimstone' that our previous generations were afraid to question." Another felt that people could not believe that the unborn baby could have sin on its soul.

What was viewed as the inherent cruelty of Limbo was picked up, unprompted, by three respondents. "People think Limbo is a . . . cruel place and don't think that children go there. They believe in a more merciful God and that children will go to Heaven directly." The related comments were: "People became more educated and realised that people cannot suffer in a manner like [as] is described in Hell"; and "People began to think it was too cruel to have innocent babies going there [Limbo]." In a somewhat similar vein, a mother added pithily: "Because people didn't buy it anymore" while another, from County Tipperary, felt the radio and television presenter, Gay Byrne played a role in liberalizing attitudes. She also drew attention to the declining moral authority of priests in Irish society. Finally, a few respondents mentioned more vaguely "change in society" as the reason for the decline in belief in Limbo without indicating what they regarded as the vital influences. ${ }^{51}$

Then there is the minority who saw change as endogenous, that is, as coming from within the Catholic Church itself. By the beginning of the 1970s, according to one such response, "there was a new way of baptism where the priest welcomed the Mam, Dad, baby and other members of the family at the door of the Church [and] the priest blessed the whole family." According to another mother: "it must have been something to do with a change of focus within the catholic church-possibly combined with more hospital births and lower mortality rates."

Not wholly surprisingly, the Second Vatican Council (1962-1965) and the reforms it introduced is mentioned as a well-spring of renewal. ${ }^{52}$ "Before Vatican II people had to adhere to strict regulations in the Church. After Vatican II Rules were relaxed." There is an edge of criticism from another mother: "Church changed its attitude, and not before time." The most elaborate explanation of the evolution of Church teaching, and not necessarily approving of the direction of change, came from a mother in County Dublin. It also helpfully outlines some of the theological considerations.

As you know, Limbo was never a defined dogma of the Catholic Church but was a theological consequence of the dogma of Original Sin and the necessity of Baptism. There is no doubt it was a heartbreaking conclusion for any involved in such a death. But the teaching said that the child would remain in a state of perfect happiness in Limbo, a place Jesus visited between His death and His resurrection. .

After Vatican II, when churchmen decided it was to be a NICE Church, the very idea that a child born dead or a child dying before baptism did not go straight to heaven was seen as UNACCEPTABLE. Limbo was downgraded from a THEOLOGICAL CONCLUSION to a THEORY. [Capitals as in the original.]

\section{Social and Religious Change}

The winds of social change blew increasingly strongly through Irish society in the second half of the twentieth century. Rising living standards, increased access to secondary- and tertiary-level 
education, the advent of television, the widespread adoption of contraception, greater equality between the sexes and a decline in clerical vocations were just some of the manifestations of social change. ${ }^{53}$ Liturgical and other reforming tendencies within the Catholic Church, most notably the fallout from Vatican Council II, contributed to the mix. Critiques by individual priests and nuns, as well as radically new theologies, had their part to play. ${ }^{54}$ From the 1990 s onward, as the scale of clerical sex abuse and the ill-treatment of single mothers by church-run institutions became apparent, ecclesiastical and clerical authority took further batterings. If anything, the pace of change in Ireland has been accelerating in the early twenty-first century with the recognition of divorce and same-sex marriage, and an acceptance of abortion under certain circumstances. ${ }^{55}$ Not all would agree that all of these revisions to traditional attitudes and practices - what might loosely be termed a process of secularization - have been for the good. The diversity of responses in the survey suggests as much. And to put this in a wider context, in many respects what has been happening in Ireland is part and parcel of a wider European pattern of social and cultural change since the 1960s, or what some might view as the increasing secularization of society. ${ }^{56}$

Within this context of change, one of the least remarked shifts within Irish society in the last fifty to sixty years has been the transition from early to late baptism. Yet it is one replete with emotional, social, theological and gender implications. The gradual and largely unremarked movement toward late baptism meant that the mother, who after all bears the burden of childbirth, can be present at the joyous moment of introducing the infant into her community of faith, an occasion enhanced by the presence of friends, relatives and loved ones. She is no longer excluded, in effect if not in formal terms, from the ceremony as in times past. The associated matter of churching, a source of resentment to some mothers, has been abolished and a different blessing ceremony substituted in its place. The rejection of Limbo in popular understanding of the fate of the unbaptized infant - the theological position is more open-ended ${ }^{57}$ - has also served to reduce a part of the anguish surrounding infant mortality.

Relaxing the belief in Limbo clearly mattered. "Younger parents today have a different outlook. They no longer believe that an unbaptised baby will go to hell." More pointedly, another mother observed: "Because the doctrine of Limbo is no longer believed within the modern Church ... there is no real hurry to baptise children nowadays." If so, this suggests that instruction in belief in Limbo, at a pastoral level, is no longer carried out and that even the possibility of the existence of Limbo has been quietly set aside.

The health and presence of the mother are also given prominence. "Parents, especially mothers, wish to be fit and healthy to attend [the] baptism of their child. Years ago children were baptised in their mother's absence." Or, as another put it, baptism is delayed to allow the mother to recover after childbirth and allow both parents to participate in the festivities. One mother provided a spiritual rationale: "Parents need time to understand the sacrament," while several raised concerns as to the depth of religious conviction in contemporary society: The "value of the sacrament has gone for most young people," said one; “The new generation don't believe," reported another. One simply wrote "Lack of Faith."

The occasion of baptism has been elaborated into an occasion of celebration and festivity for the extended family, with the center of gravity moving from the baptistery to the home: "Nowadays Baptism of a baby seems to be geared towards a party and celebration," complained one mother "and the Sacrament is not thought about as much." and emigration, particularly from rural and small-town Ireland, there are undoubtedly dilemmas of timing and location for some families. One mother explains: "I would consider that parents nowadays would consider the convenience aspect of having their friends and families attend, rather than any consideration of the Church teachings." Another mother, while critical of the modern tendencies, largely agrees on the importance of the social. "Nowadays Baptisms are like Weddings, a big 
show. I don't think it's about the Sacrament of Baptism anymore. It's all about the show, dressing up, the party after, celebrating for the wrong reasons. It's a pity."

Implicit in many of the testimonies, one suspects, and finding explicit recognition in three of the accounts is an emphasis on improved infant mortality. In all three cases a modernization-type argument is combined with an altered vision of Limbo and its perils. Thus, according to one of these, the retreat from early baptism has to do, firstly, with the superior healthcare provided for babies nowadays - falling infant mortality — and secondly, a shift in religious consciousness ("parents don't fear or know about Limbo anymore"). And another: "There is no pressure to bring forward the event as there is no fear of limbo, infant mortality is probably lower so the fear of something happening the baby may not be as great as previously."

\section{Conclusion}

Some general conclusions follow, though some are more in the nature of hypotheses to encourage further reflection and research. The conventional understanding of childhood is that of a period of life between birth and adolescence, though as Philippe Aries demonstrated long ago for medieval and post-medieval Europe the meanings have varied over time and between cultures. ${ }^{59}$ The Limbo controversy, which is inextricably bound up with notions of the infant, the human soul and the afterlife, suggests that we might enlarge the concept of childhood to embrace life in the womb, life after birth, and the afterlife of the fetus or child in the event of death. Some grieving families, as we have seen, believed in a continuing existence for their departed child, albeit translated into another but equally real world (according to their lights). Thus, protective feelings and relationships enveloping child and family did not cease with death. Such imagined states may seem strange when viewed from the perspective of secular western culture but it bears emphasizing that perceived realities of the kind recounted here presented few challenges to the religious world view of earlier generations. Maybe the boot should be on the other foot. Perhaps what is needed is more imagination on the part of skeptical historians and others, allowing a deeper appreciation of the complex inner lives of believers whom we know believed without reservation in the simultaneous existence of different worlds, of which only one was of the earthly kind. The sentiments of Sheridan Gilley, even if overstated, are worth recalling: "The secular mentality ... cannot grasp the self-understanding of a religious people who live not only for this life but for another." 60

Among Catholic parents in Ireland, in the Irish diaspora and in the Catholic universe more generally, religious and hence social assumptions and practices surrounding miscarriages, still-births and neonatal deaths formed part of the understanding of childhood, though presumably to varying degrees. For observant Catholics, the fetus was and is an unborn child. This assumption has obvious and contested implications for female sexuality and the control of fertility but these closely related themes would take us too far afield. Less well known are some of the baptism practices under medical care that were validated by this belief system and that have been alluded to earlier. Baptism in utero was permissible as were other forms of bodily intervention that affected the expectant mother physically and presumably psychologically as well.

The driving force for early baptism and even pre-natal baptismal procedures was belief in Heaven, Limbo and eternal life, though the related fear of exclusion from burial in consecrated ground also mattered and may have impelled a rejection of clerical authority in modern times, as has been argued for post-Catholic Quebec. ${ }^{61}$ Yet there appears to be no secure scriptural basis for the notion of Limbo, nor did it ever enter into "the dogmatic definitions of the Magisterium" (the teaching authority of the Catholic Church). Nonetheless, it was taught to the faithful for centuries until the period of the Second Vatican Council at least. ${ }^{62}$ Perhaps the heart of the matter, as Professor Vincent Comerford has suggested, is that Limbo is "one particular instance of obtuse dogma devised to secure institutional control." 
To add a further supposition, the quiet but cumulative change in intimate areas of family life of the kind sketched here might also exemplify shifting power relationships between Church and laity, between male celibate priests and independently-minded women, and between different generations of Irish people. ${ }^{64}$ In some ancient maps the legend "here be monsters" denoted the edges of the known world, only to be banished by advances in cartography. In somewhat analogous fashion, and under new theological and humanitarian understandings, Limbo has disappeared from lay people's spiritual and mental maps. How the belief fares with pastors is less clear-cut but there are no hints, from this survey at any rate, to suggest that traditional teachings are being perpetuated. ${ }^{65}$ To all intents and purposes Limbo is a forgotten place; it is one of those worlds, to paraphrase Peter Laslett, which we have lost, almost unconsciously so. ${ }^{66}$

How and why it went into decline would benefit from further research. A majority of the women's voices represented here favored a demand-side interpretation (to draw on the analytical framework of economics), that is that belief in Limbo receded because Irish women no longer "bought" (accepted) views that had been impressed on them through religious socialization. A variety of mutually reinforcing social changes, of the kind indicated earlier, produced this shift in understandings. The major emphasis, therefore, is on social change and female agency. Mothers, and presumably fathers as well, were acting independently of clerical authority and shaping the ceremony of baptism round their own needs and their understandings of life after death. But space was found by a minority of the respondents for a supply-side interpretation, that is that the institutional church itself quietly turned off the tap of teachings, images and strictures on the subject. In all likelihood, these two very different sets of forces were converging on a similar point in the later twentieth century.

In this study, twenty-six women have created a tapestry of many colors. The darker colors relate to fear of a child descending into an uncertain and possibly dismal state, that of Limbo. Many, though by no means all, took the arguments about the fate of unbaptized babies to constitute a cruel doctrine, and one not perhaps consistent with the notion of a benevolent God or a modern sensibility. It is impossible to read through the body of testimonies as a whole without making the inference that many Irish mothers suffered silently the intense pain of miscarriage, of stillbirth, and of infant death. Denial of access to consecrated burial ground added to the burden. This hidden suffering, which is part of the history of childhood as well as of motherhood, surfaces from time to time in the responses. For a variety of reasons, including long periods of exposure to pregnancy in a largely non-contraceptive society, including exposure to higher-risk pregnancies toward the end of the child-bearing years, many Catholic mothers in the past must have experienced one or more of these life tragedies. In addition to the normal human experiences of grief and loss, some mothers appear to have been burdened by feelings of guilt regarding the fate of the unbaptized. Speaking of Limbo, the Irish theologian, Professor Eamonn Conway has acknowledged: "I do understand why many people of a particular generation found this cruel and damaging." While the ultimate objective, in his view, was "to protect the freedom of faith," he concluded that the teaching of Limbo was a well-meaning attempt to solve a theological problem but one that caused many mothers to suffer. ${ }^{67}$ This might serve as an epitaph for a time and a belief that burdened some, possibly many parents, and women most of all.

\section{Acknowledgments}

I am grateful for the comments and criticisms of many colleagues, in particular Irene Boada, Seán Connolly, Romola Davenport, Katherine A. Lynch, Don MacRaild, Cormac Ó Gráda, Lucia Pozzi, Hugh Turpin, members of the Institute of Irish Studies at Queen's University, Belfast, and three anonymous referees. The thoughtful suggestions of Vincent Comerford are particularly appreciated. 


\section{Declaration of Conflicting Interests}

The author(s) declared no potential conflicts of interest with respect to the research, authorship, and/or publication of this article.

\section{Funding}

The author(s) received no financial support for the research, authorship, and/or publication of this article.

\section{Notes}

1. Eoin O'Mahony, Religious Practice and Values in Ireland: A Summary of European Values Study 4th Wave Data (Maynooth, Republic of Ireland: Council for Research and Development, 2010), accessed May 08, 2019, https://www.catholicbishops.ie/wp-content/uploads/images/stories/cco_publications/researcha nddevelopment/evs_4th_wave_report.pdf.

2. From a voluminous literature across various disciplines, one might select Mary E. Daly, Sixties Ireland: Reshaping the Economy, State and Society, 1957-1973 (Cambridge, UK: Cambridge University Press, 2016); J. W. O'Hagan, ed., The Economy of Ireland: Policy and Performance of a Small European Country (Dublin, Republic of Ireland: Macmillan, 1995); Deirdre Raftery and Karin Fischer, eds., Educating Ireland: Schooling and Social Change, 1700-2000 (Dublin, Republic of Ireland: Irish Academic Press, 2014); Peter Murray and Maria Feeney, Church, State and Social Science in Ireland: Knowledge Institutions and the Rebalancing of Power, 1937-73 (Manchester, UK: Manchester University Press, 2017); Mary Raftery and Eoin O'Sullivan, Suffer the Little Children: The Inside Story of Ireland's Industrial Schools (Dublin, Republic of Ireland: New Island Books, 1999).

3. Incisive discussions may be found in Diarmaid Ferriter, The Transformation of Ireland, 1900-2000 (London, UK: Profile Books, 2004); R. F. Foster, Luck and the Irish: A Brief History of Change, c. 1970-2000 (London, UK: Penguin, 2008); Tom Inglis, Moral Monopoly: The Rise and Fall of the Catholic Church in Modern Ireland (2nd ed., Dublin, Republic of Ireland: University College Dublin Press, 1998); Anthony Bradley and Maryann Gialanella Valiulis eds., Gender and Sexuality in Modern Ireland (Amherst, MA: University of Massachusetts Press, 1997). For the long view, there are relevant essays in Eugenio F. Biagini and Mary E. Daly, eds., The Cambridge Social History of Ireland (Cambridge, UK: Cambridge University Press, 2017). See in particular Colin Barr and Daithí Ó Corráin, "Catholic Ireland, 1740-2016," 68-87, and Lindsey Earner-Byrne and Diane Urquhart "Gender Roles in Ireland since 1740, , 312-26.

4. This is still one of the highest attendance rates in Europe, according to the European Social Survey of 2016. A summary of the findings by the Catholic Iona Institute, accessed July 5, 2019, https://ionainstitute.ie/ma jor-new-survey-shows-36pc-of-irish-still-attend-church-weekly-or-more/.

5. Lindsey Earner-Byrne, Mother and Child: Maternity and Child Welfare in Dublin, 1922-60 (Manchester, UK: Manchester University Press, 2007), 222.

6. Inglis, Moral Monopoly (1998); Bradley and Gialanella Valiulis, eds., Gender and Sexuality (1997); Linda Connolly, The Irish Women's Movement: From Revolution to Devolution (Dublin, Republic of Ireland: Lilliput Press, 2003); Jennifer Redmond, et al., eds., Sexual Politics in Modern Ireland (Dublin, Republic of Ireland: Irish Academic Press, 2015). Cara Delay's Irish Women and the Creation of Modern Catholicism, 1850-1950 (Manchester, UK: Manchester University Press, 2019) has a revealing focus on lay Catholic women during the century of Church ascendancy within Irish society.

7. A Catechism of Catholic Doctrine: Approved by the Archbishops and Bishops of Ireland (Dublin, Republic of Ireland: Gill \&Co., 1951). Nor was this of recent vintage. A catechism, written in Irish and Latin and published in Brussels in 1639, The "Cathechismus" of Theobald Stapleton, also speaks of the necessity of baptism and of a place apart for unbaptized infants. This work, a product of Counter-Reformation Catholicism, was reproduced by the Irish Manuscripts Commission, Dublin, in 1945.

8. New Catholic Encyclopedia (New York: McGraw-Hill, 8, 1967), 762.

9. Ibid., 2, 1056. 
10. Diarmaid MacCulloch, Reformation: Europe's House Divided, 1490-1700 (London, UK: Penguin, 2004), $11-12$.

11. New Catholic Encyclopedia, 2, 70.

12. The Irish Countrywomen's Association is a countrywide organization dedicated to improving the standard of life of rural and urban women. See Aileen Heverin, The Irish Countrywomen's Association: A History, 1910-2000 (Dublin, Republic of Ireland: Wolfhound Press, 2000).

13. Paul Thompson and Joanna Bornat, The Voice of the Past: Oral History (4th ed., Oxford, UK: Oxford University Press, 2017), 225.

14. Penny Summerfield, "Culture and Composure: Creating Narratives of the Gendered Self in Oral History Interviews," Cultural and Social History 1 no. 1 (2004): 65.

15. Louise Fuller, Irish Catholicism since 1950: The Undoing of a Culture (Dublin, Republic of Ireland: Gill \& Macmillan, 2004), 121-22, 250-53; Hugh Turpin, "Leaving Roman Catholicism," in Handbook of Leaving Religion, ed. Daniel Enstedt, Goran Larsson, and Teemu T. Mantsinen (Boston, MA: Brill Handbooks on Contemporary Religion, 2019), 186-99.

16. On the fervent Catholicism of most Irish people across most of the twentieth century, see Inglis, Moral Monopoly, 129-39, and Ferriter, The Transformation of Ireland, 517-23, 571-86.

17. A celebrated literary depiction of Hell is that by the writer, James Joyce, in his Portrait of the Artist as a Young Man (London, UK: Heinemann, 1973) but as many can testify these images of excruciating suffering were not confined to the pages of fiction. Within living memory Redemptorist priests conducted missions across urban and rural Ireland highlighting the snares of the devil and the punishments that awaited sinners in the next life.

18. B. R. Mitchell, European Historical Statistics, 1750-1970 (London, UK: Macmillan 1978), 39-44.

19. Annual reports of the Registrar-General for Saorstát Éireann and the later publication by the Central Statistics Office, edited by Adrian Redmond, That Was Then, This Is Now: Change in Ireland, 1949-1999 (Dublin, Republic of Ireland: Central Statistics Office, 2000).

20. Based on an examination of three Catholic baptism registers by the author in widely separated parts of Ireland. These are a parish in central Belfast, a parish in North Tipperary and a parish on the Dingle peninsula in County Kerry. Unless these are highly unrepresentative, the records indicate that typically, the date of birth and the date of baptism were within a few days of each other in Catholic Ireland up to the early 1960s.

21. Conversations on emergency baptism in August 2016, and again in August 2017, with a retired consultant who worked for many years at Portlaoise Hospital, in the Irish midlands. He related that sometimes, in the event of a stillbirth, the remains were placed secretly in the coffin of an adult corpse so as to gain surreptitious access to consecrated ground.

22. Conversations and correspondence with the parish priest of Baile an Fheirtéaraigh, an tAthair Eoin Ó Cadhla, 2017-19.

23. Catholic Medical Guardian: The Quarterly Journal of the Guild of St. Luke, St. Cosmas, and St. Damian, 2 (1924): 117-20. This journal circulated among Catholic doctors in Ireland; copies may be consulted at the Central Catholic Library, Dublin.

24. Jolien Gijbels, "L’Omnipresence de la Religion: Les Médecins Belges et la Dilemme Obstétrical, 18401880," Annales de Démographie Historique 139, no. 1 (Forthcoming, 2020). According to Gijbels, baptismal syringes were distributed in Catholic countries from the eighteenth century onward, and an improved version was invented by a Belgian doctor around 1845. Italian sources, according to Dr. Lucia Pozzi (personal communication), speak of the practice of "battezzato nell'utero della madre" (baptized in the mother's womb). See also Gijbels, "Medical Compromise and its Limits: Religious Concerns and the Postmortem Caesarean Section in Nineteenth-century Belgium," Bulletin of the History of Medicine 93 (2019): 305-34. The imperative to ensure the benefits of baptism for the fetus included the postmortem extraction of the unborn from the woman's belly, sometimes by Belgian priests or midwives under their direction, 323-30.

25. Fernand Leroy, Histoire de Naitre (Brussels, Belgium: De Boeck, 2001), 95, 267. 
26. On the medical and ethical conflicts, this gave rise to in the United States, including postmortem caesarean sections motivated by a concern for the baptism of the unborn, see Joseph Ryan, "The Chapel and the Operating Room: The Struggle of Roman Catholic Clergy, Physicians, and Believers with the Dilemmas of Obstetric Surgery, 1800-1900," Bulletin of the History of Medicine 76 (2002): 461-94.

27. Ciara Breathnach, ““ ... it Would be Preposterous to Bring A Protestant Here': Religion, Provincial Politics and District Nurses in Ireland, 1890-1904," in Healthcare in Ireland and Britain 1850-1970: Voluntary, Regional and Comparative Perspectives, ed., Virginia Crossman and D. S. Lucey (London, UK: University of London Press, 2015), 161-80; James Deeny and Eric T. Murdock, "Infant Mortality in the City of Belfast," Journal of the Statistical and Social Inquiry Society of Ireland 17 (1943-1944): 220-39; Gijbels, "L’Omniprésence de la Religion," (2020); Ryan, "Chapel and Operating Theatre," (2002); Earner-Byrne, Mother and Child, 120-44.

28. Charles H. G. McAfee, “The Evolution of Obstetric Conscience," Ulster Medical Journal 18 (1949): 129-42. Roughly half of all births even in the city of Belfast, for instance, were home births as late as the mid-1940s.

29. Lists of baptism fees are not easy to come by, but there are good series in the baptism registers for St. Mary's in the city of Belfast, Moycullen and Castlegar in County Galway, Cappagh in County Tyrone, and Magheralin in County Down.

30. Kevin Knight, "Churching of Women," New Advent, accessed June 12, 2017, http://www.newadvent.org/ca then/03761a.htm. On "churching" and its meaning in early modern Ireland, see Clodagh Tait, "Safely Delivered: Childbirth, Wet-nursing, Gossip-feasts and Churching in Ireland c.1530-1690," Irish Economic \& Social History 30 (2003): 19-23. For the later twentieth century, see Fuller, Irish Catholicism, 117.

31. In view of the timing, this is almost certainly a reference to the new rite of thanksgiving for a safe birth (though the term "churching" is used in her response).

32. Her first child was born in 1975 which gives a rough indication of the generation to which she belonged.

33. Fuller, Irish Catholicism, 116-18.

34. This is likely an example of how discourses round the role and status of women were reshaping understandings of the past. Such feelings should not be generalized to older women in the sample.

35. Inglis, Moral Monopoly (1998).

36. John Montague, “A Lost Tradition,” The Rough Field (Dublin, Republic of Ireland: Dolmen Press, 1972). In related vein, see Eileen Battersby, "Reading the Landscape," Irish Times, June 14, 1997.

37. Eileen M. Murphy, "Children's Burial Grounds in Ireland (Cillini) and Parental Emotions towards Infant Death," Irish Journal of Historical Archaeology 15 (2011): 409-28; Aidan O'Sullivan et al., Early Medieval Ireland AD 400-1100: The Evidence from Archaeological Excavations (Dublin, Republic of Ireland: Royal Irish Academy, 2014), 311. Also excluded were the remains of murdered infants. On infanticide, see Elaine Farrell, “A Most Diabolical Deed": Infanticide and Irish Society, 1850-1900 (Manchester, UK: Manchester University Press, 2013).

38. On the frequency of maternal mortality in Ireland and other European societies, see Lucia Pozzi, Liam Kennedy, and Matteo Manfredini, "Too Long a Sacrifice? Maternal Mortality in Northern Ireland during the First Half of the Twentieth Century," Annales de Demographie Historique 139, no. 1 (Forthcoming, 2020). A reason for this particular exclusion from consecrated ground might be because the mother's corpse enfolded the remains of an infant still tainted by original sin.

39. There are extensive references to cillíní and unbaptized babies in the archives of the National Folklore Collection (NFC), University College, Dublin. The quote in the main text is from the Schools Collection (1937-1939) and the Irish-speaking interviewee is the seventy-five-year-old Seán M. Ó Ríordáin, Gleann Beiche. Unlike the women in our survey, and this is true of other interviewees, he does not enter into any discussion of Limbo-its shapes, colors, form — but the feelings of fear and loneliness are made plain. Much of this massive archive of oral testimony from the NFC is now accessible on the Dúchas website at https://www.duchas.ie/en/cbes.

40. Observations on local cillíní by two Dingle-based scholars, Dr Breandán Ó Cíobháin and the late Monsignor Pádraig Ó Fiannachta, as well as those by Hazel Morrison of Moycullen Heritage Society, County Galway, are warmly acknowledged. 
41. Colm J. Donnelly and Eileen M. Murphy, "Children's Burial Grounds (Cillíní) in Ireland: New Insights into an Early Modern Tradition," in Oxford Handbook of the Archaeology of Childhood, ed. Sally Crawford, Dawn M. Hadley, and Gillian Shepherd (Oxford, UK: Oxford University Press, 2018), 609-30. A pioneering study (in Irish) of cillíní is that by the archivist and folklorist Seán Ó Súilleabháin, "Adhlacadh Leanbhí," Journal of the Royal Society of Antiquaries of Ireland 69 (1939): 143-51. Its speculation that cillíní are of pre-Christian origin, however, seems misplaced.

42. Donnelly and Murphy, "Children's Burial Grounds," 609-610. Two-thirds of the total of 1,444 have been located in three counties only, the western seaboard counties of Mayo, Galway and Kerry. The numbers are set to increase as local communities as well as archaeologists, in further acts of recovery, seek to read the landscape more closely.

43. Irish Times, February 2, 2011. An article in the Cork Examiner, August 15, 2012, mentions "Angel Plots" in a number of other cemeteries.

44. Belfast Telegraph, May 26, 2010.

45. A British Broadcasting Corporation Radio 2 program, "Limbo Babies," broadcast Tuesday, November 30 , 2010, spoke to parents whose stillborn infants were refused burial in consecrated ground. "In a rare personal testimony, mums, dads and families describe the harsh effects of this centuries-old practice on their lives. Many of them secretly buried their children as close as they could to consecrated ground, or in desolate, beautiful locations they felt had been touched by God," accessed October 8, 2020, https://www.bbc. co.uk/programmes/b00wdpcx.

46. Marie Rooney, "Where Do the Dead Go?" Dublin Review of Books no. 111 (May 2019). The adaptive or therapeutic value of "continuing bonds" is, however, the subject of controversy and may vary by cultural context and circumstance. For further discussion, see Briana L. Root and Julie J. Exline, "The Role of Continuing Bonds in Coping with Grief: Overview and Future Directions," Death Studies 31 (2014): 1-8.

47. "New Service Lets Parents Voice Grief at Losing A Baby," The Irish Times, June 11, 2019.

48. The Church of Ireland baptism records for St. Werburg's and St. Mary's in Dublin city and of Dingle in County Kerry, as well as the Presbyterian records for Clonmel, County Tipperary, as examined by the author, show a wide and widening gap between baptism and birth dates over the last two centuries. For a larger sample of parishes and some discussion, see William Paul Gray, "A Social History of Illegitimacy in Ireland from the Late Eighteenth to the Early Twentieth Century," PhD diss., Queen's University, Belfast, 2000.

49. Same-sex marriage was legalized in May 2015 (The Irish Times, May 23, 2015).

50. Thompson and Bornat, The Voice of the Past, chap. 7, "Evidence," 118-237.

51. Parallel lines of interpretation on the decline of traditional Catholicism may be found in Fuller, Irish Catholicism (2004); Turpin, "Leaving Catholicism," (2019); and Connolly, From Revolution to Devolution (2003).

52. For a wide-ranging assessment, see Niall Coll, ed., Ireland \& Vatican II: Essays Theological, Pastoral and Educational (Dublin, Republic of Ireland: Columba Press, 2015).

53. The implications for religious practice are considered at length in Fuller, Irish Catholicism (2004), and in a more general way in the huge sociological and historical literature on contemporary Ireland.

54. In the Irish context, these may be followed through the pages of the Furrow, Irish Ecclesiastical Record, Irish Theological Quarterly, and religious newspapers such as the The Irish Catholic.

55. To cite one quantitative measure of the direction and scale of change, in 1983, two-thirds of voters agreed to write a prohibition (the Eight Amendment) on abortion into the Irish Constitution. In 2018, in another referendum, two-thirds of voters favored deletion of that amendment, opening the way to legal abortion in Ireland.

56. However, the all-purpose notion of secularization is not without its critics. See Callum G. Brown and Michael Snape, eds., Secularisation in the Christian World (Farnham, UK: Ashgate, 2010).

57. International Theological Commission, The Hope of Salvation for Infants Who Die Before Being Baptised, accessed June 20, 2017, http://www.vatican.va/roman_curia/congregations/cfaith/cti_documents/rc_con_ cfaith_doc_20070419_un-baptised-infants_en.html. This authoritative statement from the Vatican sets out the current theological understanding of Limbo whose existence has now been downgraded to that of a "hypothesis." In other words, it is no longer an article of faith (if it ever was), and there are grounds for 
believing that unbaptized infants may enter Heaven. Still, and contrary to much lay Catholic opinion, there is no certainty of entry to Heaven without baptism, and so the continuing importance of early baptism.

58. The locus classicus for Catholic beliefs and practices in pre-Famine Ireland, including sociability surrounding vital events, is S. J. Connolly, Priests and People in Pre-Famine Ireland (Dublin, Republic of Ireland: Four Courts Press, 2001).

59. Philippe Aries, Centuries of Childhood: A Social History of Family Life (London, UK: Jonathan Cape, 1973). On Ireland, see Mary Hatfield, Jutta Kruse, and Ríona Nic Congáil, eds., Historical Perspectives on Parenthood and Childhood in Ireland (Dublin, Republic of Ireland: Arlen House, 2018).

60. Sheridan Gilley, "The Roman Catholic Church and the Nineteenth-century Irish Diaspora," Journal of Ecclesiastical History 35, no. 2 (1984): 206. See also the references to "continuing bonds" in footnote 46.

61. The latter seems to have been the dominant motive in the case of Catholics in Quebec. See Marie-Aimée Cliche, "Les Limbes: Opinions Théologiques et Croyances Populaires au Québec du XV11 au XX Siécle," Revue d'Histoire de l'Amérique Francaise 62, no. 3-4 (2009): 351-76.

62. The work of the International Theological Commission (2007), cited earlier, states: "The idea of Limbo, which the Church has used for many centuries to designate the destiny of infants who die without Baptism, has no clear foundation in revelation, even though it has long been used in traditional theological teaching."

63. Personal communication, July 19, 2020.

64. Roy Foster might well see the abandonment of traditional forms of baptism as further vindication of his thesis: "How the Catholics became Protestants." This is the somewhat impish title of chapter two of Luck and the Irish: A Brief History of Change, 1970-2000, 37-66. London, UK: Allen Lane, 2007.

65. I have spoken to a small number of Irish Catholic priests about the "doctrine" of Limbo. None expressed a belief in its existence; two seemed to regard it as a quaint notion from the past. That said, it is worth recalling that as late as the 1990s, the catechism produced by Veritas, Ireland's leading religious publisher and retailer, still insisted: "The Church does not know of any means other than Baptism that assures entry into eternal beatitude." Cathecism of the Catholic Church (Dublin, Republic of Ireland: Geoffrey Chapman, 1994), 285. It is surely significant in terms of the wider Catholic world that this was an English translation of the New Catechism produced by the Vatican (during the long pontificate of the conservative Pope John Paul II) and not simply a local Irish publication.

66. Peter Laslett, The World We Have Lost (London, UK: Methuen, 1971).

67. Irish Catholic, November 15, 2018. The headline for the article ran: "Limbo was harmful solution to a theological problem, says priest."

\section{Author Biography}

Liam Kennedy is emeritus professor of history, Queen's University, Belfast. He is the author of a number of books on Irish and Ulster history, with particular reference to long-run economic and demographic change. More recently he has engaged with Irish political history and women's history. He is a member of the Royal Irish Academy and a fellow of the Royal Historical Society. His recent publications indicate his current research interests and include: Who was Responsible for the Troubles? The Northern Ireland Conflict (Montreal, Canada: McGill-Queen's University Press, 2020); Unhappy the Land: The Most Oppressed People Ever, the Irish? (Dublin, Republic of Ireland: Merrion Press, 2016); co-edited with Philip Ollerenshaw, Ulster since 1600: Politics, Economy \& Society (Oxford University Press, 2013); with Lucia Pozzi and Matteo Manfredini, "Too Long a Sacrifice? Maternal Deaths in Northern Ireland during the first half of the 20th Century," Annales de Demographie Historique 139, no. 1 (2020); with Lucia Pozzi and Matteo Manfredini, "Did Mothers' Lives Matter? The Protection and Promotion of Maternal and Infant Health from the 16th to the 20th Century," introduction to a special issue of Annales de Demographie Historique 139, no. 1 (2020). 